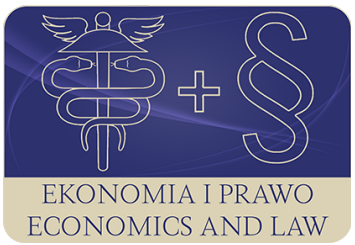

EKONOMIA I PRAWO. ECONOMICS AND LAW

Volume 20, Issue 2, June 2021

p-ISSN 1898-2255, e-ISSN 2392-1625

www.economicsandlaw.pl

ORIGINAL ARTICLE

received 30.04.2021; revised 20.06.2021; accepted 30.06.2021

Citation: Mieleszko, M. (2021). Institutional changes in politics. Ekonomia i Prawo. Economics and Law, 20(2), 305-315.

https://doi.org/10.12775/EiP.2021.018.

\title{
Institutional changes in politics
}

\author{
ANNA MIELESZKO \\ University in Białystok, Faculty of Economics and Finance, Department of Political Economy, \\ ul. Warszawska 63, 15-062 Białystok, Poland \\ ఐa.mieleszko@uwb.edu.pl \\ (D) orcid.org/0000-0003-4964-1629
}

\begin{abstract}
Motivation: Institutions are a set of rules of the game, norms and values that constitute a fundamental element of any social and political system. Political institutions are an important object of theoretical considerations and a number of attempts at explanations in political science. in their research, they put more emphasis on the effects of political institutions than on issues related to their genesis and the changes taking place. This article is in the trend of New Institutionalism which focuses on the causal role and the limited ability to design new tools, as well as a strong intention in this area.

Aim: The aim of the article is to provide a synthetic overview of the causes and effects of continuity and changes in formal political institutions within the interdisciplinary area - new institutionalism. The research methods used during the preparation of the article include the analysis and criticism of the literature

Results: The article focuses on presenting the role of institutions in political life, showing the dysfunctionality of the institutional sphere in the face of pressure from interest groups and the game of political actors. The explanation of these aspects was served by logical constructions and analyzes, primarily of a historical and sociological study, emphasizing the importance of determinants of informal institutions on the durability and institutional change.
\end{abstract}

Keywords: new institutionalism; informal institutions; institutional changes; economic JEL: E02; O46; P16; P48

\section{Introduction}

In the new institutional economics the strong emphasis is lying down for political factors and the role of couples in the forming oneself of institutional structure. 
During analysis of coming into existence of these structures and their continuity it isn't possible to turn power structures off from considering the influence. It isn't possible to ignore the role policies. Moreover activity of the state is closely associated with the forming and keeping the effective institutional system. A row of policy instruments affecting the development of the effective institutional structure is being listed in literature. They are it is among others a back-up policy competition, liberalization of the trade, building up the information society, increasing the transparency of action of politicians and the government.

Synthetic discussing the continuity of the institutional structure in the politics is a purpose of the present article with in the interdisciplinary area of the research. The new institutional economics is spreading through borderlands of the social science so as sociology, economics, history and the political science and the law. Formal institutions private and public, functioning in the sphere of the politics and economies, a copyright among others protecting system of justice, ownership transfer, provisions and voting rights are an object of analysis. It is worthwhile emphasizing that institutions are a product of human preferences of the past closer to political decision-makers or more distant, therefore are taking time in order to accommodate oneself to political and social new conditions.

\section{Literature review}

\subsection{The role of the institution in the political life}

The politics in including the institutional economics is a form of the realization of the joint property which requires establishing the institutional order. institutions determine human relationships, their precedence and the mutual degree of the compliance. They in order to strengthen desirable norms are implementing social procedures which are a pattern of both individual and collective, current behaviours in the given community. With subject of examinations institutionalist the political system is comprehended as the network of institutions mutually tied together, including the canon of political attitudes. Getting the stability in a long stretch, but also implementations are not only a purpose of the political system of values appointed in the political program of the composition which during the election process and the power struggle got the social approval.

Before philosophers of the politics and political scientists have usually treated formal political institutions and the state as independent factors organising the communal life. Starting from the eighties the 20th century in the scientific literature a role of the quality of the institution in the promotion of economic development is more and more often emphasized (Kiser \& Ostrom, 1982). The return of an interest in institutions in the political science is an effect of current institutional conversions. Stalking contemporary political scientists is empha- 
sizing the fact that political events are secondary phenomena (Acemoglu et al., 2020 , p. 15). A tendency of the conduct of research is also visible empirical from the scope of the institutional new economy. They are proving that formal and informal institutions are deciding on the success or the economic defeat of the country.

This work is focused on matters of formal institutions created by political organizations and the government. The author on purpose in analysis isn't taking meaning of informal institutions into consideration. They are these are recorded templates for thinking and keeping and attitudes, norms and myths socially acceptable in the anytime (Coccia, 2018, p. 340). Informal institutions are organising a deep-rooted and stable system of values being applicable in a given historical time and a place which is being appointed as a result of institutional long-lasting processes initiated by the society.

From analysis details turned off of scientific debate concerning defining the institutional order stayed. In the article for use of further deliberations, a definition entered by the classical representative of the institutional economics was admitted. North (1990, pp. 59-60) is defining institutions as the rules of the game to which they are applying in the society and are aimed at creating the stable structure of the report and interpersonal behaviours which next will reduce the universal uncertainty. The Noble prizewinner is returning the attention of players: the group of people orientated to the common goal which are acting in the framework of fixed rules by institutions. The players are organizations and in defined objectives, among others are players government agencies, political parties, offices of the control and the regulation of the enterprise and clubs at non-governmental organizations. Famous coming expression from North works, institutions matter, he is emphasizing the rank of examinations of institutions conducted a search in the scope which are significant, because policies are increasing the effectiveness and are supporting the growth in the economy. However still an ambiguous answer to questions is lacking initiating institutional changes by political actors for the possibility and in what way to create effective and best institutions.

The formal political institutions are structures which from one side are exerting influence on direction and the intensification of the activity of business entities. From the other side they are limiting effects of people are creating possibilities of functioning in new areas. Political institutions include with one's influence various actions of people and can be fed up loose or the strongest impact for the conduct of individuals. Therefore they aren't a loose set of elements, but stay in the strong relation. The formal institutions form the coherent institutional system. Economists are also emphasizing meaning of the relation between the efficiency of functioning of the institutional arrangement and the quality of the conducted economic policy. At their works they are emphasizing the important part of the government in creating favourable conditions for the growth in the economy and the success of the conducted economic policy (Borkowski, 2021). Also a pressure on the soil of institutional surroundings which is de- 
termined by the administrative and legal framework is being put. According to this relation individual individuals, as well as the government and business entities are entering mutual interactions so that obtain the income and raise the prosperity. Next the quality of the institution considerably influences organizational decisions and investment states and of enterprises and to the principle of distribution of the benefit. Nevertheless from the literature review, of relation including empirical examinations, examining between the economic policy and the quality of the institution, a conclusion is emerging, that the good economic policy requires supporting by strong institutions (Brzozowski et al., 2007).

Rich countries are the ones, in which efficient institutional surroundings provide the ownership transfer for investors, are creating stimuli for the business activity and social. The rule of law and the monetary policy are being kept in such countries and fiscal are rooted in long-lasting economic institutions (Mickiewicz et al., 2021). He is creating welfare states conditions for citizens until further notice oneself to freedoms and citizenship rights and the political representation in the parliament. Only countries which are able to build the solid institutional matrix, can achieve the long-lasting growth in the economy.

\subsection{Institutional change}

Political institutions undeniably constitute important factors cleaning the changeable scene of the politics up. They alone are also changing. They are these are rules of a game between citizens, experts and administration which can be modified, or transformed or replaced new (Durkalec, 2015). It isn't so straight, since institutions aren't reflecting the current condition, but they are strengthening historical experience. These rules last deciding longer than the given political situation. He is happening this way, since current institutional arrangements constitute remains of history. Also a phenomenon of the delay in the adaptation and a pace of accommodating oneself are important of institution for environmental changes. Before new political actors will manage to transform the political system, it they will most probably be removed from the political landscape, driven by other, equally short-lived layout of forces. What's more if political institutions were subject to a close and immediate inspection, managing public affairs would look totally different than in fact.

Formal political institutions, unlike the institution of economic organizations, are resistant to changes. Once established institutions have tendencies of long lasting (Pierson, 2000). Designers of the institution on purpose are preventing potential political rivals from efficient leading of changes in the future. In many cases they are creating the institutional structure, for which alone they cannot control, or manipulate her or modernize. The lack of the possibility of control is proving the perspective of implementing changes in functioning to the lack to the institution of already functioning institutions. Therefore every 
attempt to implement institutional reforms is connected from very often with great problems.

A few types of institutional changes exist: washing, putting, moving and transforming (Mahoney \& Thelen, 2010, p. 16). Fitting new institutions is usually taking place to already existing as a result of their alteration in the face of changing social and economic conditions. This type of the institutional change is aimed at streamlining the entire system by transforming and moving (Gruszewska, 2011). The process of transformations of the institution can be held by building power up existing and complementing them and in the result complementary putting new institutions on existing solutions. Changes in the system of the institution can also rely on gradual washing and ultimately eliminating existing solutions. Creation of new order in the face of the destruction old is the most radical form of formal changes of political institutions. This type of the institutional change has the greatest poignancy to the society as a whole.

Initiating changes in functioning of formal institutions is connected with a few problems. Transforming everyone complicated and a sequence of action and the reaction is evoking the complex system. The complexity of the institution is obscuring the structure cause and effect of the entire system. He is happening this way, because political actors should plan the sequence of possible social reactions. In order to understand final effects of reforms, an institution needs to look at possible responses of the society for changes. The failure to consider of causalities and omitting their results in the past are conducting many unexpected consequences. In this situation changes can bring vague unintentional effects which are contrary to intentions of interest groups (March \& Olson, 1989).

As part of appearing of the phenomenon of the growing income consolidating often takes place of the underdog of the institutional arrangement. The Noble prizewinner is using the concept path dependence in order to explain crucial factors making impossible fast transformations of the structure of the arrangement of political institutions. According to the researcher's building long-lasting legal grounds as well as producing the new institution are taking time, since at designing the new solution one should also consider long-lasting unofficial principles (North, 1990). With reference to the above the amendment of the rules of the game to the institutional arrangement is connected with danger of the deterioration of the situation social. Also a probability of loss of the expenditure incurred at forming verifying institutions which in given conditions are working is increasing.

\section{Methods}

The article uses a critical analytical and research method. This research is a synthesis of the literature on the theory of institutions and institutional changes in politics. This is to underline the theoretical basis of the study. This was done by identifying relevant articles from various search databases. Keywords such 
as institutions, institutional theory, new institutionalism, informal institutions, institutional change were used to search for the title, summary and full text. By viewing the search results, irrelevant articles were filtered out. It covers the analysis and criticism of the literature on the subject in the field of new institutional economics. The research focuses not on the influence of political institutions, but on problems related to their origins and changes taking place in them. This was achieved through logical constructions and analyzes, primarily the interpretation of theoretical models in the context of theory. The literature review also includes the current state of research related to the subject of the work, as well as English-language literature published in recent years.

\section{Results}

The first politically motivated decisions are supporting coming into existence of economic and social nets folded up. Accepted institutional arrangements in the past given are bringing the row of political and social consequences. He is happening this way, because in the reaction to make assumptions of the institution, individuals and organizations are assuming permanent obligations. In the process transactions cost are going up while going back to the decision from the past because a confusion is increasing while implementing changes institutional. Unwitting making conditional is taking place oneself societies from made decisions. Considering restrictions of picked direction of changes, political from the past is affecting more late results in the possible sequence of events.

The moment of adopting the standard fundamental assumptions at the codification of the law in the past is determining the current parameters of the politics. An order of appearing factors shaping political reality is also significant, because is reducing the number of available alternatives as well as an efficient exit from the path dependence is disqualifying (Mieleszko, 2020). The dependence on the trail isn't a spontaneous process. Political actors consciously are deciding on which institutional arrangements accepted by them will survive in the long-term. So the form of the current institutional arrangement is reflecting the pursued policy in the past. History has a primary importance, since if events in earlier phases chose other path, they would stay strengthened in more distant stages of the development. On the legal validity of legal documents stateowned new organisations are being obligated to live. Legal documents passed in the past by the present government are determining character of found political reality (Pieliński, 2013). On the legal validity of legal documents stateowned new organisations are being obligated to live. When a change of political actors and a takeover are taking place through the alternative option, a need for the amendment to the law exists. He is happening this way, because election enforcement of political program is forcing the need into creating of them of the regulation and the organization. It is affecting in turns in the effect of the entire political landscape adapted for needs of the new ruling elite. 
Paying attention to the strong report the place among institutions and preferences of the electorate is a next important aspect at this work. Political institutions are shaping preferences of individuals, since are building the political identity of all sorts social groups. Public institutions forming a team of principles and values are an effect of performed social roles and political. The group identity of one group can be many times contrary to identities of other interest group (Koroso et al., 2019). However action taken by the state is changing the disintegration of political businesses the rules of the game, creating new actors and new identities. Institutions very much influence to forms of the mobilization of individuals and social groups and to the confidence level for the power amongst citizens, as well as influence aspiration of political community. Economic reforms and social are fixing criteria for actors to the success and road to the failure. Institutional changes are equipping some individuals with new kinds of resources, and other are depriving of the power (March \& Olson, 1989). As a result they can change transforming the layout of political institutions political environment. The contact with norms and rules of functioning of different policies is also shaping the political landscape.

Institutional factors are being singled out from crucial elements which are granting the peculiar shape a new political programme,. They are granting the right capacity, the shape and the quality of the implemented politics public intervention. Moreover the new present government, implementing the given politics determined in an electoral programme, must at first gain the appropriate institutional potential. With next essential element, implementing public politics, there are actors, because are performing their roles at individual stages of the cycle of the political program.

Using formal political institutions the power is shaping the public sentiment. The ability of the state to influence business simultaneously can threaten the sovereignty of people and will make the public change control impossible institutional. After all the democratic system works thanks to the mutual confidence and institutionalised restrictions. It is worthwhile emphasizing that political actors aren't using at the height of the possibility of autonomous action, because it would threaten the democratic system. For this reason strengthening the confidence and keeping restrictions are an essential element of the institutional continuity.

In economics growing economies of scale and action of the intensifying income is being called lock in the path. It is increased is discouraging costs of adopting earlier alternatives to the exit from the path (Owczarczuk, 2013). Lock in the path is making it impossible to use from often of better institutional options. The first decision is reducing the possibility of alternative solutions, because after the certain time is bringing more and more great benefits. The phenomenon of the intensifying income causes the both positive and negative life cycles. Turning these cycles away without intervention from the outside is practically impossible. 
Understanding political processes is becoming complete in the moment of including in analysis of institutional restrictions which considerably influence real behaviours of political actors. They can carry out, or get around appointed and socially acceptable behaviour norms. The manner of functioning of the most important state institutions largely is conditioned with the type of the party system, the quality of political parties and their strategy and the way of leading the dialogue, i.e. the political culture. Only one way exists for the absconding from the trap of lock in the path. Brian Arthur claims that only intervention of some external force or the developmental shock enable the change of picked direction of the development. which will change the structure of the political system or in the radical way will convert the interrelation occurring between employed actors (Shchegolev \& Hayat, 2018).

\section{Conclusion}

With reference to changes of formal institutions, the bargaining power of interest groups is reflecting their connections with the government. Interest groups, i.e. political groups, of connection professional and business, can exert influence on the policy-making. They can refuse to support and put the threat of expensive consequences forward for the government (Kuźma, 2020). Interest groups can initiate and support the restructuring of formal institutions, or can transform them and block, in order to result of economic reforms and social was working to their advantage. Many times institutional changes result from the change in preferential treatment of political actors. It is attesting to their bargaining power (Bukowski, 2013). The lack of the autonomy of the government towards interest groups is contributing to coming into existence of new conditions and the rules of the game.

Empirical observation is showing that internal processes in changes of political institutions influence the course of history. They can be triggered with outside events based on the collective interest or intention of political actors. Next reforming initiatives of interest groups often bring different effects than planned. He is happening this way from for face of the problem in implementing intentional political transformations. Institutions are supporting their being and are resisting towards for changes, therefore of theses adapting new political actors isn't immediate (Rudolf, 2017). It is effect of adopting oneself of the rules of the game. Nested bad formal and unofficial institutions don't let for achieving the efficient institutional order during real crises. Those crises are touching specific people of their places of employment, incomes of households and the economic security in the future.

Depending on the current of the institutional economics, researchers of this interdisciplinary approach are singling out the row of different causes of the malfunction of the institutional order. In the smooth functioning of the institution best social, political and economic crises depict the problem in the past and at present. At analysis of the course of those crises, they are seeking shocks 
to the conclusion that they disappointed public institutions which were supposed to stand on guard by order and to protect citizens from adverse effects above all. For the weakness of political institutions economists are indicating the destructive egoism of ruling elites above all (Pieliński, 2013). Institutions very often are formulating haphazardly themselves. In literature it is cause of the social and economic poor condition. Not very significant or unpredictable events often from the past determine decision-making processes. Additionally the beginning of the path not always is rational, but can be a result of the coincidence (Szmigiel-Rawska, 2014) individual decisions are often fortuitous events which are strengthening the given path of the development or random happen. For example is a natural disasters, wars or pandemic.

In final years we notice the flimsiness of political institutions as bases of the democracy. Among others it is crisis of trusting to formal political institutions, above all to the government, political parties and constitutional courts. A row of causes of the deepening crisis of the confidence exists in the society. Very much disrespectfully to indisputable principles states of law are tricking the political elites. Political institutions have the task of streamlining functioning of individuals in the complicated social structure. In the opinion of the author of the article in fact political, a dissonance is noticeable between assumptions and the actual state of affairs. According to the idea institutions should create an optimal solution in order to secure a high standard of living for people. However in fact institutions established by the new political elites than are limiting the creativity and are impeding the development (Jabłoński, 2017).

Organizing and planning the entire institutional arrangement in all forms and signs is unreal. The complicated network of political institutions still is undergoing changes so that particular elements are able to adapt to different situations. Changes of the rules of the game have dual character. From one side it is natural process and is developing gradually, whereas on the other designers of new solutions on purpose are interfering in the shape of the institution and are changing them according to personal needs. To sum up the existence of ineffective institutions is often conditioned with business of given social groups. In the situation, in which they have the strongest impact in the shape of the politics, they can be blocked by pressure groups. Bad institutions have an ability for long lasting and can also result from the limited rationality of individuals which aren't able to predict benefits a new system can behind itself carry which. The being is also causing ineffective and obsolete solutions a societal acceptance is lacking reforms for the continuation.

\section{References}

Acemoglu, D., Egorov, G., \& Sonin, K. (2020). Institutional change and institutional persistence. NBER Working Papers, 27852, pp. 1-41. https://doi. org/10.3386/w27852. 
Borkowski, M. (2021) The quality of formal institutional subsystems of OECD countries. Ekonomia i Prawo. Economics and Law, 20(1), 21-41. https://doi. org/10.12775/eip.2021.002.

Brzozowski, M., Gieraltowski, P., \& Milczarek, D. (2007). Instytucje a polityka makroekonomiczna i wzrost gospodarczy. Uniwersytet Warszawski.

Bukowski, A. (2013) Kultura, instytucje, władza: ciągłość i zmiana porządku instytucjonalnego. Zarządzanie Publiczne, 2-3(24-25), 115-125.

Coccia, M. (2018), An introduction to the theories of institutional change. Journal of Economics Library, 5(4), 337-344. http://dx.doi.org/10.1453/jel. v5i4.1788.

Durkalec, K. (2015). Nieprawidłowości w funkcjonowaniu pamięci instytucjonalnej na przykładzie instytucji administracji publicznej: przegląd wybranych typów, przyczyn i sposobów diagnozowania problem. Kultura i Polityka, 18, 81-95.

Gruszewska, E. (2011). Dezintegracja w zinstytucjonalizowanym świecie. Ekonomia i Prawo. Economics and Law, 7(1), 49-65. https://doi.org/10.12775/ eip.2011.003.

Jabłoński, A.W. (2017). Instytucjonalne aspekty teorii polityki. Teoria Polityki, 1, 107-126. https://doi.org/10.4467/00000000tp.17.006.6585.

Kiser, L.L., \& Ostrom, E. (1982). The three worlds of action: a metatheoretical synthesis of institutional approaches. In E. Ostrom (Ed.), Strategies of political inquiry (pp. 172-222). Sage.

Koroso, N.H., Zevenbergen, J.A., \& Lengoiboni, M. (2019). Land institutions' credibility: analyzing the role of complementary institutions. Land Use Policy, 81, 553-564. https://doi.org/10.1016/j.landusepol.2018.11.026.

Kuźma, M. (2020). Rola nowej ekonomii instytucjonalnej w wyjaśnianiu procesów wzrostu i rozwoju gospodarczego. Nierówności Spoteczne a Wzrost Gospodarczy, 61(1), 55-72. https://doi.org/10.15584/nsawg.2020.1.4.

Mahoney, J., \& Thelen, K. (2010). A theory of gradual institutional change. In J. Mahoney, \& K. Thelen (Eds.), Explaining institutional change: ambiguity, agency, and power (pp. 1-37). Cambridge University Press. https://doi. org/10.1017/CBO9780511806414.003.

March, J., \& Olson, J. (1989). Rediscovering institutions: the organizational basis of politics. Free Press.

Mickiewicz, T., Stephan, U., \& Shami, M. (2021) The consequences of shortterm institutional change in the rule of law for entrepreneurship. Global Strategy Journal. Advance online publication. https://doi.org/10.1002/ gsj.1413.

Mieleszko, A. (2020). Koncepcja path dependence w ekonomii. In E. Gruszewska (Ed.), Wspótczesne problemy ekonomiczne $w$ badaniach mtodych naukowców, 4, 10-17. Uniwersytet w Białymstoku. https://doi.org/10.15290/ wpewbmn4.2020.01.

North, D.C. (1990). Institutions, institutional change and economic performance. Cambridge University Press. 
Owczarczuk, M. (2013), Zmiany instytucjonalne w gospodarce: wybrane aspekty teoretyczne. Optimum: Studia Ekonomiczne, 2(62), 26-40. https://doi. org/10.15290/ose.2013.02.62.03.

Pieliński, B. (2013). Instytucjonalizm historyczny w kontekście polityki społecznej. Problemy Polityki Spotecznej, 22 (3), 45-63.

Pierson, P. (2000) The limits of design: explaining institutional origins and change. Governance: an International Journal of Policy and Administration, 13(4), 475-499. https://doi.org/10.1111/0952-1895.00142.

Rudolf, S. (2017). Nowe spojrzenie na równowagę instytucjonalną i zmianę instytucjonalną. Prace Naukowe Uniwersytetu Ekonomicznego we Wroctawiu, 493, 22-35. https://doi.org/10.15611/pn.2017.493.02.

Shchegolev, I., \& Hayat, A. (2018). Institutional quality, governance and economic growth: evidence from former Soviet countries. Journal of Advances in Economics and Finance, 3(4), 120-127. https://doi.org/10.22606/ jaef.2018.34002.

Szmigiel-Rawska, K. (2014). Koncepcja zależności od ścieżki jako narzędzie wyjaśniania w badaniach ekonomicznej geografii politycznej. Prace i Studia Geograficzne, 54, 149-161.

\section{Acknowledgements}

Author contributions: author has given an approval to the final version of the article.

Funding: this research was funded by the author's own sources.

Note: the results of this study were presented at 4th Scientific Conference: Institutions in Theory and Practice (March 25-26, 2021, Wrocław, Poland). 
